PAPER

\title{
Evaluation of preoperative high magnetic field motor functional MRI (3 Tesla) in glioma patients by navigated electrocortical stimulation and postoperative outcome
}

\author{
K Roessler, M Donat, R Lanzenberger, K Novak, A Geissler, A Gartus, A R Tahamtan, D Milakara, \\ T Czech, M Barth, E Knosp, R Beisteiner
}

J Neurol Neurosurg Psychiatry 2005;76:1152-1157. doi: 10.1136/innp.2004.050286

See end of article for authors' affiliations

Correspondence to: Dr K Roessler, Department of Neurosurgery, or Dr R Beisteiner, Department of Neurology, Medical University of Vienna; Waehringer Guertel 1820, A-1090 Vienna, Austria; karl.roessler@ meduniwien.ac.at; roland.beisteiner@ meduniwien.ac.at

Received 20 July 2004

In revised form

17 November 2004

Accepted

18 November 2004

\begin{abstract}
Objectives: The validity of 3 Tesla motor functional magnetic resonance imaging (fMRI) in patients with gliomas involving the primary motor cortex was investigated by intraoperative navigated motor cortex stimulation (MCS).

Methods: Twenty two patients ( 10 males, 12 females, mean age 39 years, range 10-65 years) underwent preoperative $\mathrm{FMRI}$ studies, performing motor tasks including hand, foot, and mouth movements. A recently developed high field clinical fMRI technique was used to generate pre-surgical maps of functional high risk areas defining a motor focus. Motor foci were tested for validity by intraoperative motor cortex stimulation (MCS) employing image fusion and neuronavigation. Clinical outcome was assessed using the Modified Rankin Scale.

Results: FMRI motor foci were successfully detected in all patients preoperatively. In 17 of 22 patients (77.3\%), a successful stimulation of the primary motor cortex was possible. All 17 correlated patients showed $100 \%$ agreement on MCS and FMRI motor focus within $10 \mathrm{~mm}$. Technical problems during stimulation occurred in three patients (13.6\%), no motor response was elicited in two (9.1\%), and MCS induced seizures occurred in three (13.6\%). Combined FMRI and MCS mapping results allowed large resections in 20 patients (91\%) (gross total in nine (41\%), subtotal in $11(50 \%)$ ) and biopsy in two patients (9\%). Pathology revealed seven low grade and 15 high grade gliomas. Mild to moderate transient neurological deterioration occurred in six patients, and a severe hemiparesis in one. All patients recovered within 3 months (31.8\% transient, 0\% permanent morbidity).

Conclusions: The validation of clinically optimised high magnetic field motor fMRI confirms high reliability as a preoperative and intraoperative adjunct in glioma patients selected for surgery within or adjacent to the motor cortex.
\end{abstract}

effect; ${ }^{30}{ }^{31}$ however, clinical data on the validity and postoperative outcomes in patients with higher field strength (3 T) fMRI do not as yet exist.

Thus, this is to our knowledge the first study testing clinical outcome and correlation between fMRI and navigated MCS with preoperative high field $(3 \mathrm{~T})$ motor fMRI. These data should clarify whether $3 \mathrm{~T}$ fMRI results could safely be used preoperatively and intraoperatively to identify and spare motor areas during glioma surgery.

\section{PATIENTS AND METHODS Patient population}

For the study, 22 patients (mean age 39 years, range 10 to 65 ) with gliomas close to or involving the motor cortex were recruited. Clinical, radiological, and histological (according to the recent WHO classification ${ }^{32}$ ) findings and extent of resection (gross total $>99 \%$, subtotal between 90 and $99 \%$ radiological amount) as defined by an immediate postoperative MRI scan are summarised in table 1. Six patients had one previous surgery and one patient had two (previous histology in brackets). Preoperative neurological function and postoperative outcome 1 week and 3 months after surgery were assessed using the $\mathrm{MRS}^{33}$ (table 2).

Abbreviations: BOLD, blood oxygenation level dependent; fMRI, functional magnetic resonance imaging; MCS, motor cortex stimulation has the advantages of improved signal to noise ratio and enhanced blood oxygenation level dependent (BOLD) 
Table 1 Patient characteristics

\begin{tabular}{|c|c|c|c|c|c|c|c|c|c|c|c|c|}
\hline No. & Age & Tumour site & $\begin{array}{l}\text { Size } \\
(\mathrm{cm})\end{array}$ & $\begin{array}{l}\text { Pre-op } \\
\text { neurology }\end{array}$ & $\begin{array}{l}\text { FMRI } \\
\text { paradigm }\end{array}$ & $\begin{array}{l}\text { Extent } \\
\text { of } \\
\text { surgery }\end{array}$ & Histology & $\begin{array}{l}\text { MRS } \\
\text { pre-op }\end{array}$ & $\begin{array}{l}\text { MRS } \\
1 \text { week } \\
\text { post-op }\end{array}$ & $\begin{array}{l}\text { MRS } \\
3 \text { months } \\
\text { post-op }\end{array}$ & $\begin{array}{l}\text { Results MCS } \\
\text { localisation of: }\end{array}$ & $\begin{array}{l}\text { Correspondence } \\
\text { of } \mathrm{fMRI} / \mathrm{MCS} \text { in: }\end{array}$ \\
\hline 1 & 36 & $\begin{array}{l}\text { Fronto- } \\
\text { precentral } \\
\text { right }\end{array}$ & 4.5 & GM & $\begin{array}{l}\mathrm{H} / \mathrm{F} \text { left } \\
\text { motor }\end{array}$ & GT & Astro II & 0 & 0 & 0 & $\begin{array}{l}\text { Foot, lower leg, } \\
\text { thigh, forearm, } \\
\text { hand }\end{array}$ & $\begin{array}{l}\text { Foot extension, } \\
\text { finger flexion, }\end{array}$ \\
\hline 2 & 33 & Central right & 3.0 & GM, JE & $\begin{array}{l}\mathrm{H} / \mathrm{F} \text { left } \\
\text { motor }\end{array}$ & ST & $\begin{array}{l}\text { GBM/ } \\
\text { (GBM/ } \\
\text { GBM) }\end{array}$ & 0 & 0 & 0 & Hand, forearm & $\begin{array}{l}\text { Finger flexion, } \\
\text { FISIS }\end{array}$ \\
\hline 3 & 56 & $\begin{array}{l}\text { Precentral } \\
\text { right }\end{array}$ & 5.0 & JE A left & $\begin{array}{l}\mathrm{H} / \mathrm{F} \text { left } \\
\text { motor }\end{array}$ & GT & Oligo I & 0 & $5^{*}$ & 0 & Hand, forearm & $\begin{array}{l}\text { Finger flexion, } \\
\text { FISIS }\end{array}$ \\
\hline 4 & 32 & Central right & 3.0 & CPS & $\begin{array}{l}\mathrm{H} \text { left } M \\
\text { motor }\end{array}$ & GT & Astro III & 0 & 0 & 0 & $\begin{array}{l}\text { Hand, finger, } \\
\text { face }\end{array}$ & $\begin{array}{l}\text { Finger flexion/ } \\
\text { extension }\end{array}$ \\
\hline 5 & 64 & $\begin{array}{l}\text { Centro- } \\
\text { paracentral } \\
\text { left }\end{array}$ & 5.0 & JE AF right & $\begin{array}{l}\mathrm{H} / \mathrm{F} \text { left } \\
\text { motor, } \mathrm{F} \\
\text { motor }\end{array}$ & B & GBM & 2 & 2 & 2 & Foot, lower leg & Foot extension \\
\hline 6 & 49 & $\begin{array}{l}\text { Precentral } \\
\text { right }\end{array}$ & 4.0 & GM & $\mathrm{H} / \mathrm{F}$ left $M$ & ST & Astro III & 0 & $2^{*}$ & 0 & Hand & Finger flexion \\
\hline 7 & 38 & $\begin{array}{l}\text { Postcentral } \\
\text { left }\end{array}$ & 6.0 & $H H$, Cogn. & $\mathrm{H} /$ right $\mathrm{M}$ & GT & GBM & 1 & 1 & 1 & Hand, forearm & Finger movements \\
\hline 8 & 41 & Central left & 5.0 & Aphasia & FA flex right & ST & $\begin{array}{l}\text { GBM/ } \\
\text { (Astro III) }\end{array}$ & 2 & 2 & 2 & Excluded & NMR \\
\hline 9 & 33 & $\begin{array}{l}\text { Fronto- } \\
\text { central left }\end{array}$ & 4.5 & CPS & $\begin{array}{l}\mathrm{H} / \mathrm{F} \text { right } \\
\text { motor }\end{array}$ & ST & Astro II & 0 & $2^{*}$ & 0 & Hand, & Finger flexion \\
\hline 10 & 56 & Central left & 2.5 & JE A right & $\begin{array}{l}\mathrm{H} \text { right } \\
\text { motor }\end{array}$ & ST & GBM & 0 & $2^{*}$ & 0 & Hand, forearm & Finger flexion \\
\hline 11 & 29 & $\begin{array}{l}\text { Centro- } \\
\text { postcentral } \\
\text { right }\end{array}$ & 2.5 & $\begin{array}{l}\text { JE AF } \\
\text { left,GM }\end{array}$ & $\begin{array}{l}\text { H left motor/ } \\
\text { sensory }\end{array}$ & GT & Oligo I & 0 & 0 & 0 & $\begin{array}{l}\text { Hand, forearm, } \\
\text { shoulder }\end{array}$ & $\begin{array}{l}\text { Finger flexion, } \\
\text { FISIS }\end{array}$ \\
\hline 12 & 45 & $\begin{array}{l}\text { Postcentral } \\
\text { left }\end{array}$ & 4.0 & CPS & $\begin{array}{l}\text { H right } \\
\text { motor/ } \\
\text { sensory }\end{array}$ & GT & $\begin{array}{l}\text { AstrollI / } \\
\text { (astro II) }\end{array}$ & 0 & 0 & 0 & Excluded & Technical problem \\
\hline 13 & 13 & $\begin{array}{l}\text { Centro- } \\
\text { temporal } \\
\text { right }\end{array}$ & 2.0 & CPS, JE & $\begin{array}{l}\mathrm{H} \text { left } M \\
\text { motor }\end{array}$ & ST & $\begin{array}{l}\text { Ganglio- } \\
\text { glioma II/ } \\
\text { (I) }\end{array}$ & 0 & $2^{*}$ & 0 & Face, tongue & $\begin{array}{l}\text { Face contraction, } \\
\text { tongue movement }\end{array}$ \\
\hline 14 & 31 & Central left & 3.0 & $\begin{array}{l}\text { JA face/HP } \\
\text { right }\end{array}$ & $\begin{array}{l}\mathrm{H} \text { right } \mathrm{M} \\
\text { motor }\end{array}$ & B & $\begin{array}{l}\text { GBM/ } \\
\text { astroll }\end{array}$ & 2 & 2 & 2 & Hand, forearm & Finger flexion \\
\hline 15 & 40 & $\begin{array}{l}\text { Centro- } \\
\text { insular right }\end{array}$ & 3.0 & HP left & $\begin{array}{l}\mathrm{H} \text { left } M \\
\text { motor }\end{array}$ & ST & $\begin{array}{l}\text { GBM/ } \\
\text { (astro II)I }\end{array}$ & 3 & $4^{*}$ & 3 & Hand, forearm & $\begin{array}{l}\text { Finger flexion, } \\
\text { extension }\end{array}$ \\
\hline 16 & 44 & $\begin{array}{l}\text { Postcentral } \\
\text { left }\end{array}$ & 5.0 & CSD & $\begin{array}{l}\mathrm{H} \text { right } \\
\text { motor/ } \\
\text { sensory }\end{array}$ & GT & $\begin{array}{l}\text { Oligoastro } \\
\text { III, (astro II) }\end{array}$ & 1 & $2^{*}$ & 1 & Excluded & Technical problem \\
\hline 17 & 29 & $\begin{array}{l}\text { Precentral } \\
\text { right }\end{array}$ & 4.0 & JE face A left & $\begin{array}{l}\text { H left } M \\
\text { motor }\end{array}$ & GT & GBM & 0 & 0 & 0 & Hand, forearm & Finger flexion \\
\hline 18 & 41 & $\begin{array}{l}\text { Fronto- } \\
\text { central/ } \\
\text { paracentral }\end{array}$ & 3.0 & GM & $\begin{array}{l}\mathrm{H} / \mathrm{F} \text { left } \\
\text { motor }\end{array}$ & ST & $\begin{array}{l}\text { Oligoastro } \\
\text { III, (astro II) }\end{array}$ & 0 & 0 & 0 & $\begin{array}{l}\text { Foot, lower leg, } \\
\text { thigh, hip }\end{array}$ & Foot extension \\
\hline 19 & 14 & $\begin{array}{l}\text { Centro- } \\
\text { paracentral } \\
\text { right }\end{array}$ & 6.0 & Hhyp left & $\begin{array}{l}\text { H left motor/ } \\
\text { sensory }\end{array}$ & GT & GBM & 1 & 1 & 1 & Hand, forearm & Finger flexion \\
\hline 20 & 10 & $\begin{array}{l}\text { Postcentral } \\
\text { left }\end{array}$ & 6.0 & GM & $\begin{array}{l}\mathrm{H} / \mathrm{F} \text { right } \\
\text { motor }\end{array}$ & ST & $\begin{array}{l}\text { Astro I, } \\
\text { pilocytic }\end{array}$ & 0 & 0 & 0 & Foot, lower leg & Foot extension \\
\hline 21 & 65 & $\begin{array}{l}\text { Precentral } \\
\text { right }\end{array}$ & 4.5 & HP left & $\mathrm{H}$ left motor & ST & GBM & 2 & 2 & 2 & Excluded & Technical problem \\
\hline 22 & 55 & $\begin{array}{l}\text { Precentral } \\
\text { left }\end{array}$ & 4.0 & GM & $\begin{array}{l}\mathrm{H} / \mathrm{F} \text { right } \mathrm{M} \\
\text { motor }\end{array}$ & ST & Oligoll & 0 & 0 & 0 & Excluded & NMR \\
\hline
\end{tabular}

\section{Magnetic resonance imaging studies}

Preoperatively, all patients underwent morphological and fMRI imaging in a 3 Tesla high field MR tomograph (BRUKER Medspec 30/80, BRUKER BioSpin, Ettlingen, Germany) with a phase corrected blipped GE, single shot, EPI sequence (repetition time $4000 \mathrm{~ms}$; echo time $5.5 \mathrm{~ms}$; flip angle $90^{\circ}, 128 \times 128$ matrix, $230 \times 230$ field of view, 25 axial slices, slice thickness $3 \mathrm{~mm}$, no interslice gap, sinc pulse excitation), using an fMRI technique employing motor paradigms as described previously 34-3652 (table 1). Individually constructed plaster cast helmets for each patient were used for head fixation. ${ }^{37}$ A common anatomical reference system was defined using the Talairach approach. ${ }^{38}$
Prior to further analysis, all volumes of every subject were realigned using dedicated software (AIR $3.08{ }^{39}$ ) with a rigid six parameter (three transformation and three rotation parameters) model. Motor risk maps, ${ }^{34} 3652$ which avoid localisation errors caused by functional smoothing procedures $^{40}{ }^{41}$ were then generated. Voxel reliability was determined by evaluating the number of runs a voxel surpassed a certain correlation threshold. At various correlation thresholds, reliability values were colour coded and mapped as follows: yellow $=75-100 \%$ of runs active; orange $=50-75 \%$ of runs active; red $=25-50 \%$ of runs active (figs 1 and 2 ). The largest correlation threshold that yielded voxel clusters with voxels of a reliability $>75 \%$ was then determined. The most reliable voxel cluster was defined as the motor centre. To 


\begin{tabular}{|ll|}
\hline Table 2 & Modified Rankin Scale \\
\hline Score & Description \\
\hline 0 & $\begin{array}{l}\text { No symptoms at all } \\
\text { No significant disability despite symptoms; able to carry out }\end{array}$ \\
2 & $\begin{array}{l}\text { all usual duties and activities } \\
\text { Slight disability; unable to carry out all previous activities, but } \\
\text { able to look after own affairs without assistance }\end{array}$ \\
3 & $\begin{array}{l}\text { Moderate disability; requiring some help, but able to walk } \\
\text { without assistance } \\
\text { Moderately severe disability; unable to walk without } \\
\text { assistance and unable to attend to own bodily needs without } \\
\text { assistance }\end{array}$ \\
5 & $\begin{array}{l}\text { Severe disability; bedridden, incontinent and requiring } \\
\text { constant nursing care and attention } \\
\text { Dead }\end{array}$ \\
\hline
\end{tabular}

avoid localisation errors due to EPI distortions, motor centres were individually transferred from distorted EPI images to non-distorted anatomical images by a neuroanatomical expert in a semiautomatic fashion. ${ }^{52}$ The resulting anatomical functional dataset was used for MCS.

\section{Imaging data transfer and surgical planning}

Anatomical MRI and fMRI datasets were uploaded to the neuronavigation systems. Image correlation was carried out by mechanical data transformation in the neuronavigation system via a magneto-optical disc or, for the last 10 cases, automatically with recently available commercial software (Medtronic, Minneapolis, Minnesota, USA). The fMRI image information was transformed into digital imaging and communications in medicine (DICOM) format and split into anatomical and functional information. The anatomical $3 \mathrm{~T}$ MRI was consecutively fused with the $1.5 \mathrm{~T}$ navigation image, and exchanged with the functional image content. This procedure led to a spatially correct transformation of the fMRI images for intraoperative navigation. Preplanning of surgery and navigation was performed in the planning station of the navigation systems outside the operating theatre the day before surgery. Image registration was carried out in the operating theatre, using an established protocol, to avoid registration inaccuracies and to minimise brain shift associated inaccuracies at the beginning of stimulation mapping. ${ }^{42-44}$

\section{Intraoperative neuronavigation and motor cortex stimulation}

The patient's head was fixed in a standard head rest (Mayfield clamp; Integra, NJ, USA). Three different navigation systems were used for spatial correlations of fMRI data with intraoperative motor cortex mapping. For registration of
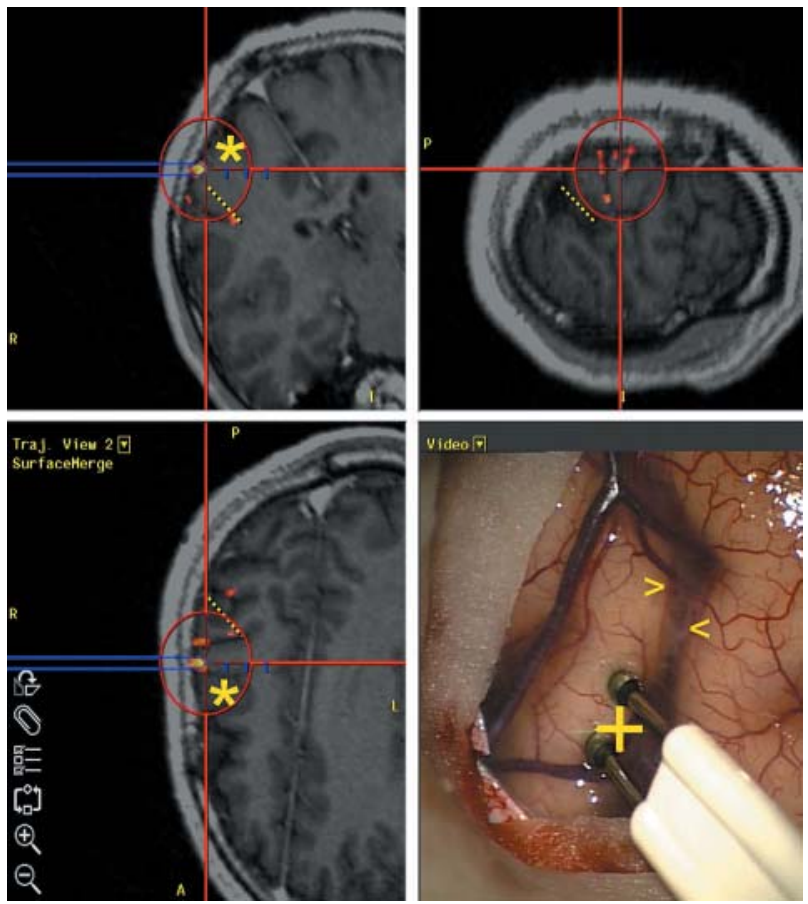

Figure 2 Intraoperative correlative stimulation mapping using neuronavigation. Intraoperative neuronavigation: FMRI was fused to structural contrast enhanced 1.5 T MRI and registered to the patient's head. A correlation analysis of anatomical details on the images and corresponding cerebral structures is possible. Electrocortical stimulation on the FMRI finger flexion extension paradigm activation area was performed with the Ojemann stimulator. Finger flexion occurs during stimulation of the cortical area, which showed the FMRI activation. *FMRI activation signal, +, corresponding cortical area identified by neuronavigation; $><$, central sulcus.

image data onto the patient's head, the infrared pointer navigation system EGN (Philips, Best, The Netherlands) was used in five patients, the infrared pointer and robotic microscope navigation system MKM (Zeiss, Oberkochen, Germany) in seven, and the infrared pointer and microscope navigation system StealthStation TREON (Medtronic, Minneapolis, Minnesota, USA) for the last 10 patients. Correlation of image data and brain structures was achieved as described earlier. ${ }^{42-44}$ When the registration procedure demonstrated a registration error (deviation of image structures and corresponding patient structures after registration) $>2 \mathrm{~mm}$, the registration was cancelled and the procedure was repeated. Spatial correlation between fMRI data and cortical mapping results was performed

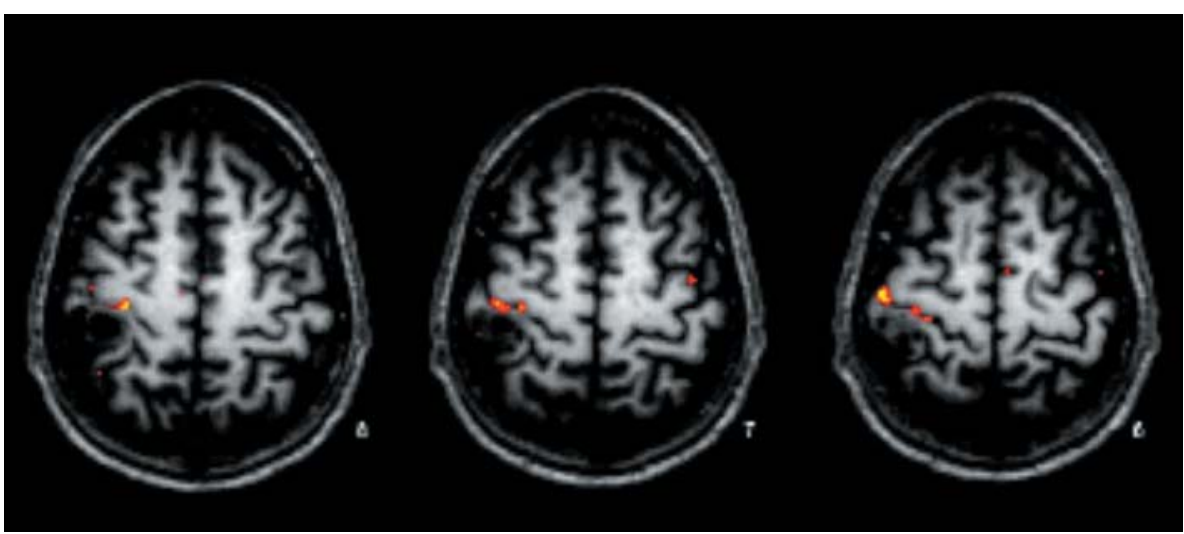

Figure 1 An fMRI risk map. Case 11: 29 year old male, presenting with focal sensible Jackson's epilepsy on the left hand and left forearm. Neuroradiological examinations revealed a hypointense, partially calcified lesion within the postcentral gyrus, next to the central sulcus and precentral knob on the right. The fMRI activation areas are visualised as yellow and red areas after performing a finger flexion extension paradigm within the $3 \mathrm{~T}$ MRI using a plaster cast helmet and repeated measurements and correlation data analysis (risk map technique ${ }^{35}{ }^{51}$ ). 
immediately after opening the dura to avoid the effect of brain shift. Motor fMRI data were outlined with the navigation system as preoperatively defined, and were stimulated along with the surrounding tissue using a bipolar stimulation electrode and electrical stimulator (Ojemann cortical stimulator OCS-1; Radionics, Germany). The current was increased stepwise from $2 \mathrm{~mA}$ to a maximum of $25 \mathrm{~mA}$, and trains of square wave pulses of $2-4 \mathrm{~ms}$ duration at $50 \mathrm{~Hz}$ were used. The effect of cortical stimulation was observed and documented by a member of the neurosurgery (or neuroanesthesiology) team. Tonic actication of contralateral limb or facial muscles was classified as positive motor response and further increase of stimulus intensity was stopped. As the main goal of this study was the investigation of the functional significance of the preoperatively defined fMRI motor focus, the motor focus and a surrounding area of about $1 \mathrm{~cm}$ was primarily mapped. Depending on the topographic relationship between tumour tissue and fMRI activation sites, areas with less reliable or no fMRI activation were additionally stimulated). Anatomical sites of stimulation responses were marked using sterile paper plates numbered with consecutive Arabic numerals and documented by photographs.

All patients were kept under total intravenous anaesthesia during the whole surgery and stimulation mapping procedure, using propofol $(6-12 \mathrm{mg} / \mathrm{kg} / \mathrm{h})$ as a sedative and remifentanyl $(0.05-2 \mu \mathrm{g} / \mathrm{kg} / \mathrm{min})$ as an analgesic drug. No muscle relaxants were used except for the induction of general anaesthesia. In three patients, focal motor seizures developed, which were easily abolished by rinsing the cortex with cold Ringer's solution ${ }^{17}$ and administering an additional bolus of 10-20 mg propofol.

\section{RESULTS}

In the study, all 22 patients (100\%) successfully demonstrated cortical activation from a finger flexion/extension paradigm in the fMRI within the precentral knob, nine patients additionally from a foot flexion/extension paradigm in the region of the motor part of the paracentral lobule, and six patients from a mouth opening/closing paradigm in the opercular part of the precentral gyrus. Motor foci representing most reliable activations at the highest possible correlation thresholds comprised only few voxels (fig 1). In 17 of the 17 patients in whom a motor response could be elicited, motor cortex stimulation at the fMRI motor focus or within an area of $1 \mathrm{~cm}$ around the focus resulted in a motor response, somatotopically corresponding to the MRI paradigm (table 1, fig 1). For safe tumour resection, mapping of tissue not activated with our fMRI paradigm was also performed. Results showed motor responses, but these were qualitatively different from the target movement (table 1). In two patients $(9.1 \%)$, no motor response could be elicited by stimulating the exposed cortex, in three patients (13.6\%), technical problems occurred during stimulation. These five patients had to be excluded from the evaluation of fMRI MCS correlation. MCS induced seizures occurred in three patients (table 1).

A gross total resection was achieved in nine patients (41\%), a subtotal resection in $11(50 \%)$, and two (9.1\%) had a biopsy as a consequence of motor responses within the tumour areas (table 1, fig 2). Transient mild or moderate neurological deterioration occurred in seven patients $(31.8 \%)$, but all patients recovered within 3 months, resulting in $0 \%$ permanent morbidity (MRS pre-operatively, 1 week and 3 months postoperatively; table 1).

\section{DISCUSSION}

Despite the controversy surrounding the prognostic significance of the extent of resection in the treatment of hemispheric gliomas, growing evidence exists that surgical resection of gliomas is beneficial for long term patient survival of high and low grade gliomas. ${ }^{1-10}$ In highly eloquent areas, such as the motor cortex, high morbidity rates are reported for resective surgery, and in most cases only biopsy or subtotal resection is advisable. ${ }^{45-48}$ Employing motor cortex stimulation, image fusion, and intraoperative neuronavigation, complications may be reduced and resection optimised. $.^{14} 1642-444950$

The role of preoperative functional MRI and its validity in glioma surgery for sparing eloquent cortex areas are still under debate. ${ }^{18-25}$ Therefore, we investigated the validity of a recently developed clinical high field motor fMRI protocol by navigated motor cortex stimulation intraoperatively, and evaluated the postoperative neurological outcome. This technique combines optimised head fixation, ${ }^{36}$ high spatial functional resolution, and evaluation of voxel reliability in high magnetic field with improved signal to noise ratio, enhanced BOLD effect (functional contrast), and reduced artefacts, as described previously. ${ }^{31} 34365253$

Preoperative fMRI motor mapping was successfully performed in all patients. A success rate superior to results using conventional lower field fMRI was achieved. ${ }^{53}$ Eloquent tissue was always detected as highly focal in the sense of voxels representing the largest probability for true positive activation within the experimental context (table 1). In 5 of 22 patients, technical problems with MCS prevented correlation of fMRI findings with stimulation results (MCS failure rate of $22.7 \%$ ), which seems high, compared with literature. ${ }^{17} 4950$ Subclinical seizure activity and repeatedly experienced problems with the technical performance of the stimulation might be the reason.

In all 17 patients, where correlation mapping was successful, a good spatial correlation of fMRI activation site and motor response similar to the activation task in fMRI was noted, indicating $100 \%$ reliability of the preoperatively detected fMRI risk areas. Compared with literature results, where best correlation mapping using image guidance with a considerable number of patients showed failure rates of up to $20 \%,{ }^{27-29}$ our results support the clinical applicability of the achieved technical refinements. Considering the $5 \mathrm{~mm}$ distance of the two poles of the stimulation probe, accuracy was guaranteed for a distance of about $10 \mathrm{~mm}$ around the motor focus, discussed as the critical distance from response site to resection margin for inducing permanent neurological deficits, ${ }^{164950}$ which we respected in every patient. In comparison, the correlation reported for magnetic source imaging for somatosensory and motor mapping ranges was within a distance of $19 \mathrm{~mm}$, with the disadvantage that magnetoencephalography units are rarely available. ${ }^{51}$

Despite the unfavourable localisation of the cerebral gliomas in the investigated patients, clinical outcome resulted in $31.8 \%$ transient morbidity. Nevertheless, this seems unacceptably high, underlining the problem with using imaging instead of biopsy for radical glioma surgery in and around the motor cortex. ${ }^{39}$ Recent reports on comparably eloquent tumour surgery within eloquent areas and with comparable amounts of resection report up to $71 \%$ transient postoperative morbidity and $5-10 \%$ permanent neurological deficits, despite application of electrocortical mapping and neuronavigation. ${ }^{45-47}$ In contrast, in our study, all patients who experienced deterioration recovered to the original preoperative MRS level, resulting in no permanent neurological morbidity.

A significant problem with preoperative fMRI as used here is that in complex clinical situations more extended mapping of primary motor cortex may be desirable. Repeated preoperative fMRI investigations with more complex motor tasks $^{34}{ }^{40}$ need to be perfomed. This, of course, would demand 
extended preoperative preparation time and data analysis work. In contrast, extended motor mapping using electrical stimulation probes takes much less time. Another problem using our improved technique is the time consuming patient preparation, with a total data acquisition and integration time for navigated surgery of about 24 hours, which is not acceptable in space occupying gliomas presenting with acute signs of increased intracranial pressure or in children. ${ }^{52}$ However there are no such restrictions for patients with low grade gliomas, and the $100 \%$ concordance of preoperative fMRI activation with intraoperative cortical mapping favours this method as a preoperative planning and intraoperative navigation assistance whenever feasible.

In summary, high field fMRI combined with specifically developed clinical fMRI technique has been demonstrated to be safe and highly reliable for motor tasks in preoperative investigation of glioma patients. Intraoperative neuronavigation guided electrocortical mapping and correlation with fMRI motor foci showed agreement within about $10 \mathrm{~mm}$ spatial resolution. This technique may add benefit in reducing postoperative morbidity when used as an adjunct to all affordable technical adjuncts for the planning of glioma surgery in motor areas.

\section{ACKNOWLEDGEMENTS}

The authors acknowledge important scientific and organisatory support by Professor Dr L Deecke (Head of the Ludwig Boltzmann Institute for Functional Brain Topography, Vienna) and by Professor Dr S Trattnig (Medical Director, MR Centre of Excellence, Department of Radiology, Medical University of Vienna).

\section{Authors' affiliations}

K Roessler, M Donat, K Novak, T Czech, E Knosp, Department of Neurosurgery Medical University of Vienna, Austria

R Lanzenberger, A Geissler, A Gartus, A R Tahamtan, D Milakara,

R Beisteiner, M Barth, Study Group Clinical fMRI at the Departments of Neurology and Radiology Medical University of Vienna, Austria R Lanzenberger, A Geissler, A Gartus, A R Tahamtan, D Milakara, R Beisteiner, Ludwig Boltzmann Institute for Functional Brain Topography Medical University of Vienna, Austria

Competing interests: none declared

\section{REFERENCES}

1 Ammirati M, Vick N, Liao YL, et al. Effect of the extent of surgical resection on survival and quality of life in patients with supratentorial glioblastomas and anaplastic astrocytomas. Neurosurgery 1987;21:201-6.

2 Piepmeier J, Christopher S, Spencer D, et al. Variations in the natural history and survival of patients with supratentorial low-grade astrocytomas. Neurosurgery 1996;38:872-8.

3 Hentschel SJ, Lang FF. Current surgical management of glioblastoma. Cancer J 2003:9:113-25.

4 Hulshof MC, Koot RW, Schimmel EC, et al. Prognostic factors in glioblastoma multiforme. 10 years experience of a single institution. Strahlenther Onkol 2001;177:283-90.

5 Scott JN, Rewcastle NB, Brasher PM, et al. Which glioblastoma multiforme patient will become a long-term survivor? A population-based study. Ann Neurol 1999;46:183-8

6 Daneyemez M, Gezen F, Canakci Z, et al. Radical surgery and reoperation in supratentorial malignant glial tumors. Minim Invasive Neurosurg 1998;41:209-13.

7 Mohan DS, Suh JH, Phan JL, et al. Outcome in elderly patients undergoing definitive surgery and radiation therapy for supratentorial glioblastoma multiforme at a tertiary care institution. Int J Radiat Oncol Biol Phys 1998;42:981-7.

8 Berger MS, Deliganis AV, Dobbins J. The effect of extent of resection on recurrence in patients with low grade cerebral hemisphere gliomas. Cancer 1994;74:1784-91.

9 Keles GE, Lamborn KR, Berger MS. Low-grade hemispheric gliomas in adults: a critical review of extent of resection as a factor influencing outcome. J Neurosurg 2001;95:735-45

10 Keles GE, Lamborn KR, Chang SM, et al. Volume of residual disease as a predictor of outcome in adult patients with recurrent supratentorial glioblastomas multiforme who are undergoing chemotherapy. J Neurosurg 2004; 100:41-6.
11 Reijneveld JC, Sitskoorn MM, Klein M, et al. Cognitive status and quality of life in patients with suspected versus proven low-grade gliomas. Neurology 2001;56:618-23

12 Roberts DW, Strohbehn JW, Hatch JF, et al. A frameless stereotaxic integration of computerized tomographic imaging and the operating microscope. J Neurosurg 1986;65:545-9.

13 Watanabe E, Watanabe T, Manaka S, et al. Three-dimensional digitizer (neuronavigator): new equipment for computed tomography-guided stereotaxic surgery. Surg Neurol 1987;27:543-7.

14 Matz PG, Cobbs C, Berger MS. Intraoperative cortical mapping as a guide to the surgical resection of gliomas. J Neurooncol 1999;42:233-45.

15 Penfield W, Boldrey E. Somatic motor and sensory representation in the cerebral cortex of man as studied by electrical stimulation. Brain 1937;37:389-443

16 Ojemann G, Ojemann J, Lettich E, et al. Cortical language localization in left, dominant hemisphere. An electrical stimulation mapping investigation in 117 patients. J Neurosurg 1989;71:316-26.

17 Sartorius CJ, Berger MS. Rapid termination of intraoperative stimulationevoked seizures with application of cold Ringer's lactate to the cortex. Technical note. J Neurosurg 1998;88:349-51.

18 Gallen CC, Sobel DF, Waltz T, et al. Noninvasive preoperative neuromagnetic mapping of somatosensory cortex. Neurosurgery 1993;33:260-8.

19 Jack CR Jr, Thompson RM, Butts RK, et al. Sensory motor cortex: correlation of preoperative mapping with functional MR imaging and invasive cortical mapping. Radiology 1994;190:85-92.

20 Yetkin FZ, Papke RA, Mark LP, et al. Location of the sensorimotor cortex: functional and conventional MR compared. Am J Neuroradiol 1995; 16:2109-13.

21 Cosgrove GR, Buchbinder BR, Jiang $H$. Functional magnetic resonance imaging for intracranial navigation. Neurosurg Clin N Am 1996;7:313-22.

22 Mueller WM, Yetkin FZ, Hammeke TA, et al. Functional magnetic resonance imaging mapping of the motor cortex in patients with cerebral tumors. Neurosurgery 1996;39:515-20.

23 Pujol J, Conesa G, Deus J, et al. Clinical application of functional magnetic resonance imaging in preoperative identification of the central sulcus. J Neurosurg, 88:863-9.

24 Krings T, Reul J, Spetzger U, et al. Functional magnetic resonance mapping of sensory motor cortex for image-guided neurosurgical intervention. Acta Neurochir (Wien) 1998;140:215-22.

25 Wilkinson ID, Romanowski CA, Jellinek DA, et al. Motor functional MRI for pre-operative and intraoperative neurosurgical guidance. $\mathrm{Br} J$ Radiol 2003;76:98-103

26 Yousry TA, Schmid UD, Jassoy AG, et al. Topography of the cortical motor hand area: prospective study with functional MR imaging and direct motor mapping at surgery. Radiology 1995; 195:23-9.

27 Schulder M, Maldjian JA, Liu WC, et al. Functional image-guided surgery of intracranial tumors located in or near the sensorimotor cortex. J Neurosurg 1998:89:412-18.

28 Lehericy S, Duffau H, Cornu P, et al. Correspondence between functional magnetic resonance imaging somatotopy and individual brain anatomy of the central region: comparison with intraoperative stimulation in patients with brain tumors. J Neurosurg 2000;92:589-98.

29 Fandino J, Kollias SS, Wieser HG, et al. Intraoperative validation of functional magnetic resonance imaging and cortical reorganization patterns in patients with brain tumors involving the primary motor cortex. J Neurosurg 1999;91:238-50.

30 Moser E, Trattnig S. 3.0 Tesla MR systems. Invest Radiol 2003;38:375-6.

31 Kruger G, Kastrup A, Glover GH. Neuroimaging at 1.5 T and 3.0 T: comparison of oxygenation-sensitive magnetic resonance imaging, Magn Reson Med 2001;45:595-604.

32 Kleihues $\mathrm{P}$, Burger PC, Scheithauer BW. The new WHO classification of brain tumours. Brain Pathol 1993;3:255-68.

33 Bonita R, Beaglehole R. Modification of Rankin Scale: Recovery of motor function after stroke. Stroke 1988;19:1497-500

34 Beisteiner $\mathbf{R}$, Windischberger $C$, Lanzenberger $R$, et al. Finger somatotopy in human motor cortex. Neuroimage 2001;13:1016-26.

35 Beisteiner R, Gartus A, Erdler M, et al. Magnetoencephalography indicates finger motor somatotopy. Eur J Neurosci 2004;19:465-72.

36 Beisteiner R, Lanzenberger R, Novak K, et al. Improvement of preoperative evaluation by generation of FMRI risk maps. Neurosci Lett 2000;290:13-16

37 Edward V, Windischberger C, Cunnington R, et al. Quantification of FMRI artifact reduction by a novel plaster cast head holder. Hum Brain Mapp 2000;11:207-13.

38 Talairach J. Co-planar stereotaxic atlas of the human brain. New York, Thieme Publishers, 1988:5

39 Woods RP, Grafton ST, Holmes CJ, et al. Automated image registration: I. General methods and intrasubject, intramodality validation. Comput Assist Tomogr 1998;22:141-54.

40 Geissler A, Lanzenberger R, Barth M, et al. Influence of fMRI smoothing procedures on replicability of fine scale motor localization. Neuroimage 2004;24:323-31.

41 Fransson $\mathbf{P}$, Merboldt KD, Petersson KM, et al. On the effects of spatial filtering-a comparative FMRI Study of episodic memory encoding at high and low resolution. Neuroimage 2002; 16:977-84.

42 Roessler K, Ungersboeck K, Dietrich W, et al. Frameless stereotactic guided neurosurgery: clinical experiences with an infrared based pointer device navigation system. Acta Neurochir 1997a;139:551-9.

43 Roessler K, Ungersboeck K, Aichholzer M, et al. Image guided neurosurgery comparing a pointer device system with a navigating 
microscope. A retrospective analysis of 208 cases. Min Invas Neurosurg 1997b;41:53-7.

44 Roessler, K. Ungersboeck, M. Aichholzer, et al. Frameless stereotactic lesion contour-guided surgery using a computer-navigated microscope. Surg Neurol 1998:49:282-9.

45 Duffau H, Capelle L, Sichez J, et al. Intra-operative direct electrical stimulations of the central nervous system: the Salpetriere experience with 60 patients. Acta Neurochir (Wien) 1999;141:1157-67.

46 Eisner W, Burtscher J, Bale R, et al. Use of neuronavigation and electrophysiology in surgery of subcortically located lesions in the sensorimotor strip. J Neurol Neurosurg Psychiatry 2002;72:378-81.

47 Duffau H, Denvil D, Capelle L. Absence of movement disorders after surgical resection of glioma invading the right striatum. J Neurosurg 2002:97:363-9.

48 Keles GE, Lundin DA, Lamborn KR, et al. Intraoperative subcortical stimulation mapping for hemispherical perirolandic gliomas located within or adjacent to the descending motor pathways: evaluation of morbidity and assessment of functional outcome in 294 patients. J Neurosurg 2004 Mar; 100:369-75.

49 Berger MS, Kincaid J, Ojemann GA, et al. Brain mapping techniques to maximize resection, safety, and seizure control in children with brain tumors. Neurosurgery 1989:25:786-92.

50 Berger MS, Ojemann GA. Intraoperative brain mapping techniques in neurooncology. Stereotact Funct Neurosurg 1992;58:153-61.

51 Schiffbaver H, Berger MS, Ferrari $P$, et al. Preoperative magnetic source imaging for brain tumor surgery: a quantitative comparison with intraoperative sensory and motor mapping. J Neurosurg 2002;97:1333-42.

52 Beisteiner R. Indikationen, Probleme und Ergebnisse der funktionellen MRT im Kindesalter. Pädiatrische Praxis 2004;64:2.

53 Krings T, Reinges MHT, Erberich S, et al. Functional MRI for presurgical planning: problems, artefacts, and solution strategies. I Neurol Neurosurg Psychiatry 2001;70:749-60.

\section{NEUROLOGICAL STAMP}

\section{Sir Thomas Lewis 1881-1945}

7

he principal contributions of Sir Thomas Lewis, who was born in Cardiff, were in cardiology and electrocardio-

graphy. He also performed research on blood vessels and pain. His observation on the sequence of events that followed stroking sensitive or normal skin with a blunt instrument, known as the "triple response", was described by Lewis in 1924, and was attributed to the release of histamine-like substance. This response is of interest to neurologists, because intrademal histamine produces a triple response (vasodilatation, weal formation, and flare) in pre-ganglionic, but not post-ganglionic brachial plexus lesions.

Lewis was honoured on a stamp produced by Mauritius in 1981, (Stanley Gibbons no. 624, and Scott no.529) on the centenary of his birth. He is shown here with an electrocardiogram.

\section{F Haas}

Department of Neurology, Wellington Hospital, Private Bag 7902, Riddiford Street, Wellington, New Zealand; Ihaas@xtra.co.nz

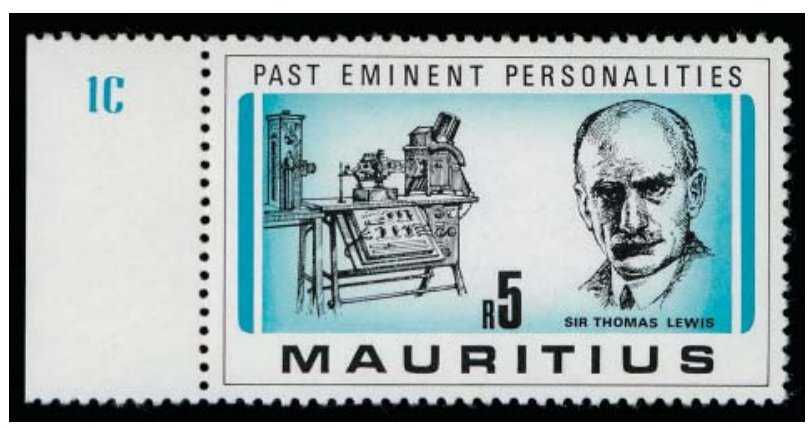

